
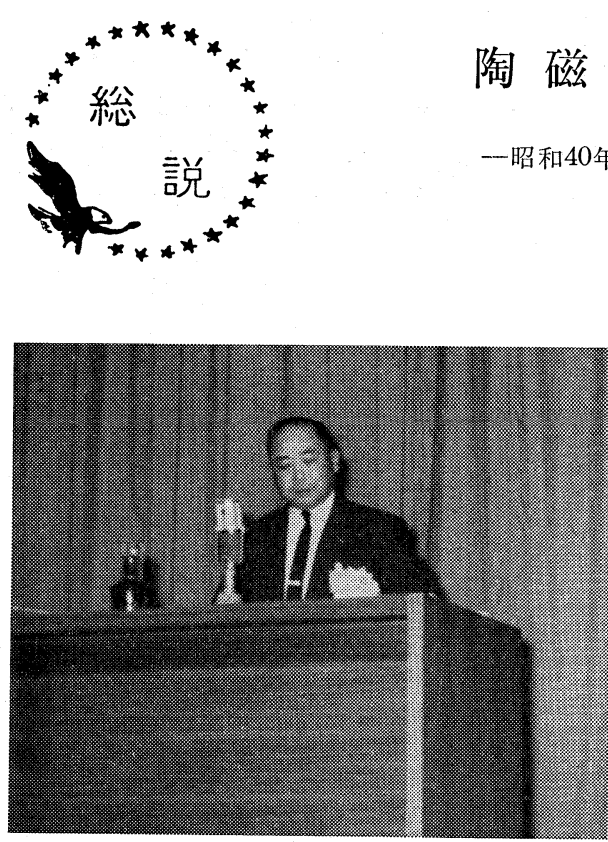

\section{I . 緒言}

陶磁器の生産は, 年とともに増加の傾向をたどり, 海外市場の開拓と相俟つてめざましい伸長をみせてい る。陶磁器工業は, 国産原料を多く使用する点, 技能 が他国より優れていることなど有望な産業の一つであ る。

燃料の使用量は, 熱管理の普及, 燒成窒の改善進歩

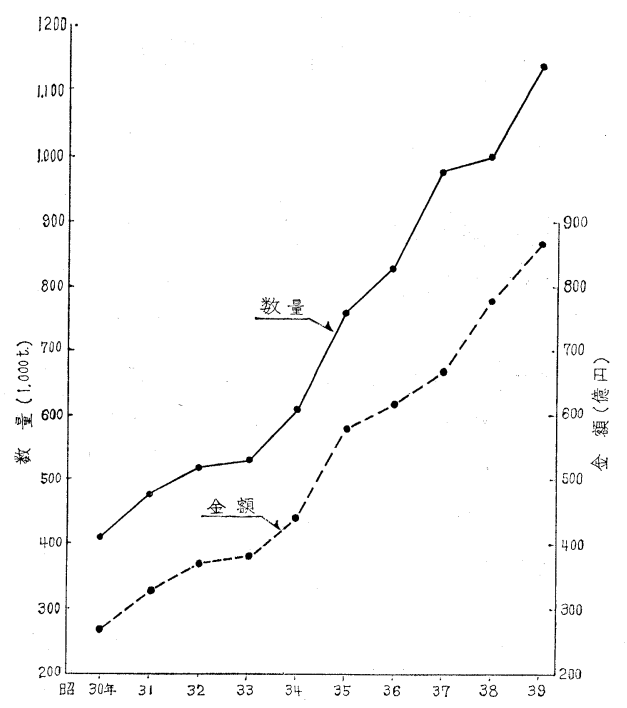

第 1 図 陶磁器生産高

（筧業建材統計年報による）

\section{陶磁器工業と燃料}

一昭和 40 年 10 月 20 日名古屋大会特別講演一

日本陶器株式会社大石”信男

などによつて，相当合理化されているが，生産の増加 によつて最近 5 力年間で約 $30 \%$ 増している。

\section{II . 陶磁器生産高の推移}

1. 陶磁器生産高

最近 5 年間における生産実績をみると第 1 図のごと くである。(弿業, 建材統計月報 通商産業大臣官房 調查局編）

昭和 35 年と昭和 39 年の生産高を比べてみると, 重 量, 金額ともに約 50\% 増加している。

$\begin{array}{lcrr} & \begin{array}{l}\text { 昭和35年 } \\ (\mathrm{B})\end{array} & \begin{array}{c}\text { 昭和39年 } \\ (\mathrm{A})\end{array} & \mathrm{B} / \mathrm{A} \\ \text { 重量 }(1,000 \mathrm{t} / \text { 年) } & 761 & 1,138 & 150 \% \\ \text { 金額 (億円/年) } & 579 & 869 & 150 \%\end{array}$

2. 陶磁器輸出高

陶磁器の輸出高は, 陶磁器全生産高のうち 約 $40 \%$ を占め,わが国の産業としてその伸長は大いに望まし いことである。

最近 5 年間の輸出の伸びは第 2 図のごとくである。 （窵業・建材統計月報）

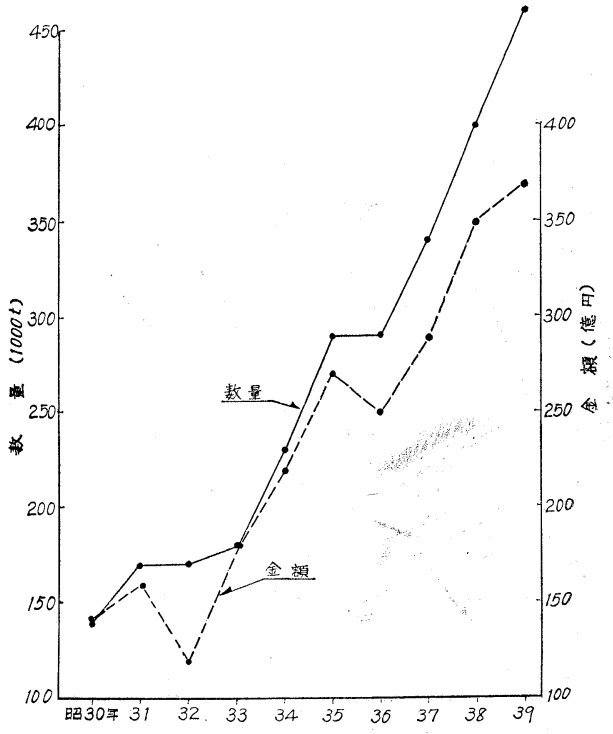

第 2 図 陶磁器輸出高

（窐業・建材統計年報による） 
昭和35年と昭和39年の生産高を比べてみると重量で 約 60\%，金額で約 $40 \%$ の増加を示している。

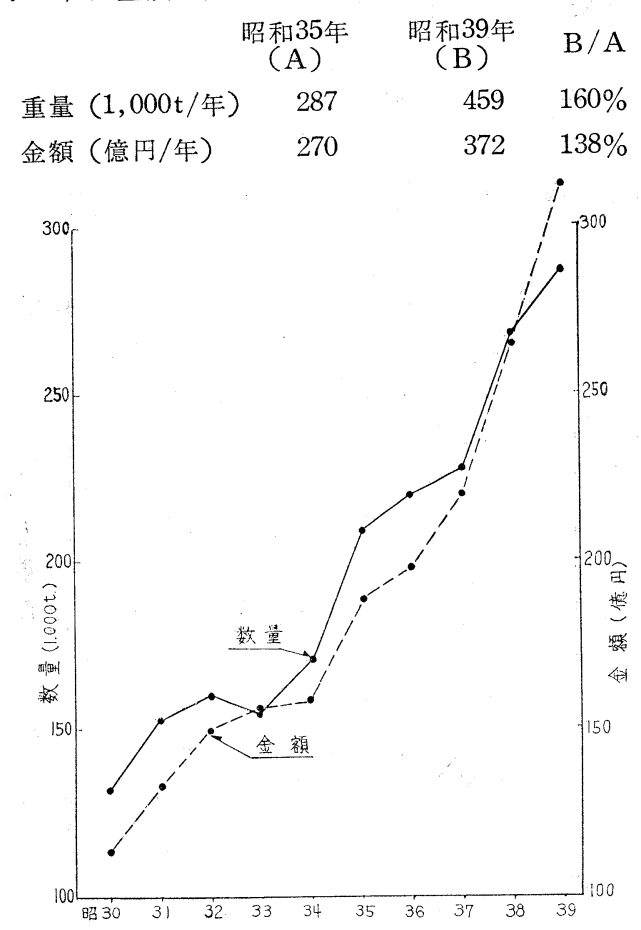

第 3 図 飲食器生産高

（割業・建材統計年報による）

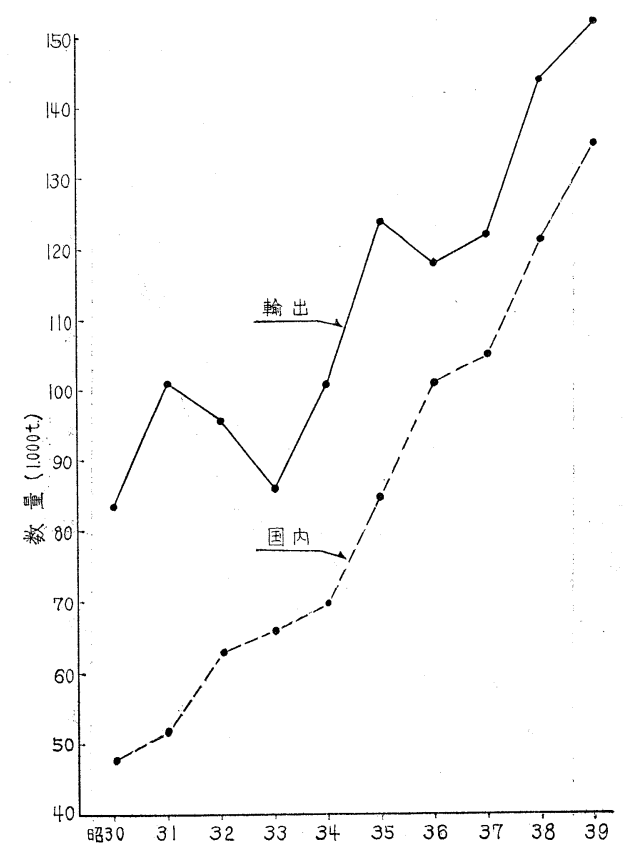

第 4 図 飲食器販売量

（突業・建材統計年報による）

\section{3. 飲食器生産高}

陶磁器のらち飲食器の生産状況は, 生産重量でみる とヨーロッパを凌駕する域に達してきた。最近 5 年間 の飲食器の全部と, 輸出および内需の生産の伸びは第 3〜5 図のごとくである。(割業・建材統計月報)

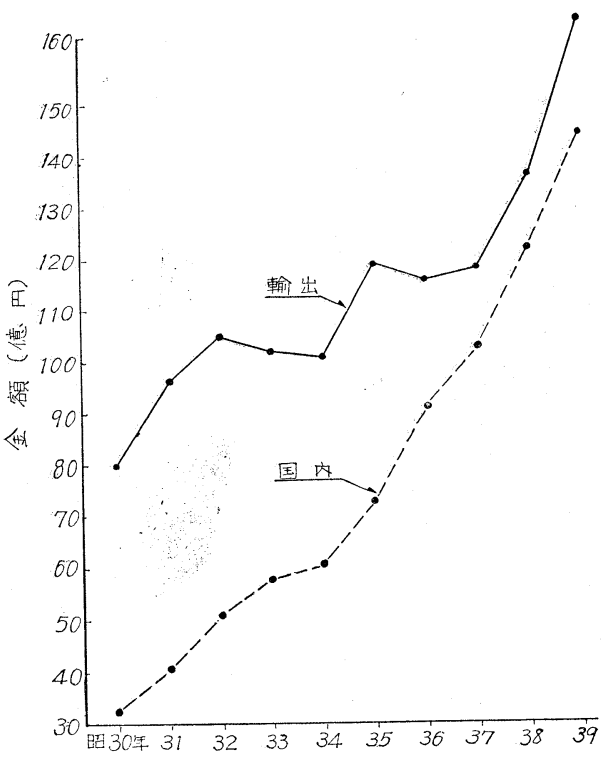

第 5 図 飲食器販売高

（搳業・建材統計年報による）

昭和35年と昭和39年を比べてみるとつぎのごとくで ある。

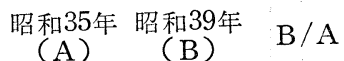

飲 食 器

全部 重量(1,000t/年) $\quad 208 \quad 287 \quad 138 \%$ 金額(億円/年) $192 \quad 307 \quad 160 \%$

輸出

重量(1,000t/年) $124 \quad 152 \quad 123 \%$

金額(億円/年) $\quad 119 \quad 163 \quad 137 \%$

内 需

$\begin{array}{llll}\text { 重量(1,000t/年) } & 84 & 135 & 161 \% \\ \text { 金額(億円/年) } & 73 & 144 & 195 \%\end{array}$

4. 県別生産実績

各県別生産高をみると, 第 6 図に示すごとく, 愛知 県, 三重県, 岐阜県が 主生産地で, 全国生産高の約 $80 \%$ を示めている。 


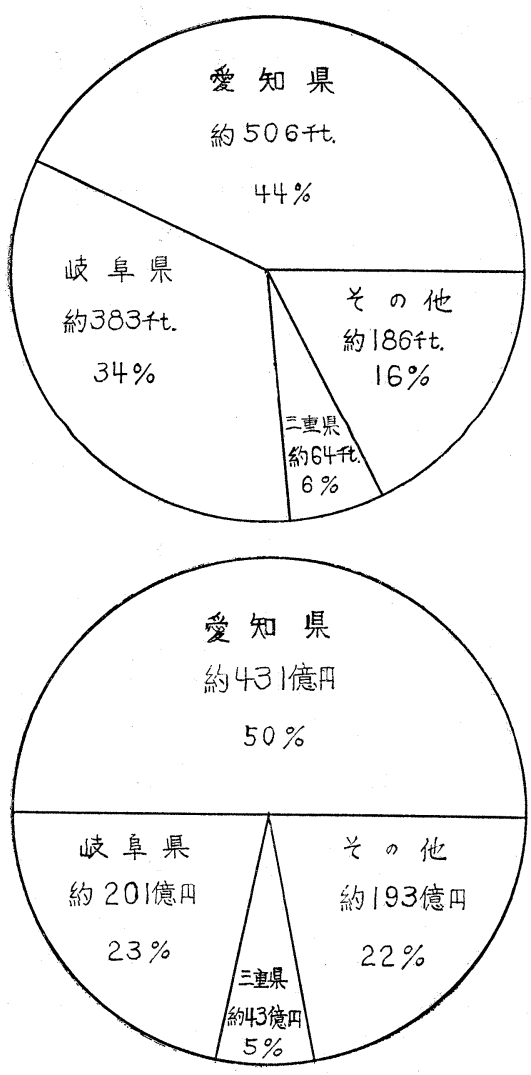

第 6 図 陶磁器県別生産高 (昭和39年)

（窐業・建材統計年報による）

5. 陶磁器生産規模現況

陶磁器工業は他工業に比べて, 中小企業が主体を占 め, 特に飲食器工業では $80 \%$ 以上が中小企業である。

これは手作業が主体で, 多大の設備, 資金を要しな
いことに起因しているが，この改善合理化は必須のこ とである。

\section{III. 窯或績の推移}

\section{1. 焼成嘿の種類}

陶磁器を焼成する窯は不連続窯, 半連続䵫および, 連続窵に大別できる。不連続の単独突は 1 窯毎に焼成 条件を自由に変更することができ, 融通性をもつてい て便利な点はあるが, 燃料面からはきわめて不経済で ある。

半連続窯は第一室の焼成中に次室は充分余熱され, また必要な空気は焼成の終つた室をとおつて加温され てくるので熱効率がよくなるが, 完全に連続式でない から冷却のために燃料が空費されることになる。

連続式トンネル窯は絶えず焼成を続行し, 冷却の必 要がないから然料経済の上から最も理想的である。

2. トンネル䆬の特徵

戦前は燃料事情からもトンネル窯は僅少であつた が，戦後重油の普及と食器のようなデリケートな品物 を焼成できるように技術が普及したため, 各製造業者 は競ってその築造を行なってきた。

1）燃料費の低減

燃焼ガスは燒成帯を過ぎてからも品物の予熱に利用 され, また冷却帯の余熱は乾燥機の熱源として利用さ れる。従つてトンネル窝では不連続単独䅁に較べて $50 \%$ 以上の然料が節減できる。

2) 炉材の保持

各位置の炉材は常時同一温度に保持され, 加熱, 冷 却を繰返す不連続窝のように熱衝撃をうけないので, 炉材の消耗が少なく 5 年も 10 年も休むことなく稼働で きる。

第 1 表 企業規模および生産内容（昭和 40 年 7 月）

\begin{tabular}{|c|c|c|c|c|c|c|c|}
\hline & & & & $\begin{array}{c}\text { 中小企業 } \\
\text { (A) }\end{array}$ & 大 企 業 & ( $\stackrel{\text { 訪 }}{\mathrm{B}})$ & $\underset{\%}{(\mathrm{~A} / \mathrm{B})}$ \\
\hline 月 & 末 従 業 員 & 数 & (人) & 66,684 & 32,911 & 99,675 & 67 \\
\hline 生 & 数 & 量 & $(t)$ & 70,037 & 33,250 & 103,287 & 68 \\
\hline 生 & 産 & 額 & (1,000円) & $4,517,048$ & $3,618,589$ & $8,135,637$ & 56 \\
\hline & (台所用品, 食卓用 & & $(t)$ & 24,474 & 3,640 & 28,114 & 87 \\
\hline 主 & タ & ル & $(t)$ & 26,409 & 20,181 & 46,590 & 57 \\
\hline 要 & 電気 用 & 品 & $(t)$ & 4,264 & 3,847 & 8,111 & 53 \\
\hline 品 & $\begin{array}{l}\text { 工業用品およひ } \\
\text { 学用品お }\end{array}$ & 化 & $(\mathrm{t})$ & 601 & 873 & 1,474 & 41 \\
\hline 目 & 術生 & 品 & $(\mathrm{t})$ & 2,114 & 3,683 & 5,797 & 36 \\
\hline & 玩 具 & 物 & $(\mathrm{t})$ & 6,709 & 981 & 7,690 & 88 \\
\hline 輸 & 数 & 量 & $(\mathrm{t})$ & 27,975 & 13,391 & 41,366 & 68 \\
\hline 輸 & 出 & 額 & (1,000円) & $2,179,827$ & $1,376,887$ & $3,556,714$ & 61 \\
\hline
\end{tabular}

注 中小企業とは資本金 5,000 万円以下のものをいら。(密業・建材統計月報による) 
3) 熱 源

電気，ガス，重油などのように連続的に供給できる 燃料を使用する。

4）焼成条件の均一化

窯内各部所の温度雲囲気を常時一定に保つておけば 連続的にバラッキの少ない品物ができる。

5）設備費

不連続窯に比べて一時的な費用がかさむ不利がある。

6）生 産

多量生産に適している。

\section{IV. 燃料使用量の推移}

陶磁器焼成用燃料は, 古くは薪材が使用され, 特に 松材は長炎であることから珍重がられていたが，明治 末期に欧米のいわゆる，石炭窯が導入されてからは， 石炭が多く使用されるようになつた。また戦後は重油 の普及が行なわれ，トンネル窝の築造と相まつて重油 の使用が激増してきた。

最近 5 年間にわたる燃料使用量をカロリ一換算して みると第 7 図のごとくである。(換算率，重油 10,000 $\mathrm{kcal} / l, 6,000 \mathrm{kcal} / \mathrm{kg}$ )

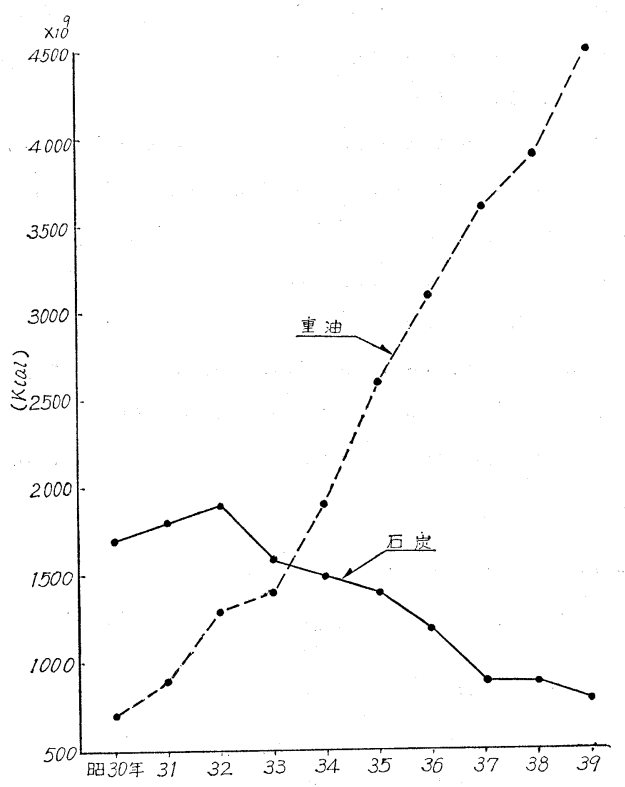

第 7 図燃料使用量 (陶磁器)

（室業・建材統計年報による）

昭和35年と昭和39年を比べてみると，石炭の使用量 は約半減しているのに対して, 重油は約 $70 \%$ 増加し ている。

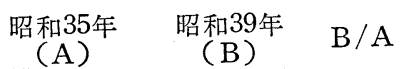

重油 (kcal) $2,616 \times 10^{9} \quad 4,535 \times 10^{9} \quad 173 \%$

石炭 (kcal) $\quad 1,410 \times 10^{9} \quad 782 \times 10^{9} \quad 55 \%$

合計 (kcal) $\quad 4,026 \times 10^{9} \quad 5,317 \times 10^{9} \quad 132 \%$

\section{V. 陶磁器焼成の概要}

ここに一例として磁器洋食器を主体とする焼成につ いて概要を述べる。

1. 素 焼

陶石, 長石, 粘土などを主体とした坏土で, 所要の 形状に成形して乾燥したものを生素地といって，これ を素焼用トンネル窯にと抢して，900 950 ${ }^{\circ} \mathrm{C}$ に加熱， 酸化雲囲気中で焼成する。生素地を素焼トンネル塞に とおすには，一般に耐火物の板を組んだ棚車が用いら れる。

\section{2. 本 燒}

素焼をした素地に釉薬を吸着させてから本燒燒成を する。その温度は $1,380^{\circ} \mathrm{C}$ ( $\left.\mathrm{SK} 13\right)$ ぐらいである。

釉薬はガラスとほぼ同質のもので, 焼成により熔融 乙器物の表面に陶磁器特有の光択を与えるものである が，これがために本焼の致詰は素焼の場合のように何 枚も直接重䄈ることができない。すなわち製品を 1 個 づつ耐火物のサヤの中に入れて積み上げて窐詰めを行 なう。

本焼の焼成は素焼の場合のように簡単ではない。す なわち $1,000^{\circ} \mathrm{C}$ 附近までは酸化焰で, これ以上の温 度においては還元焰で焼成する。ほとんど品物が熔融 変形する一歩前までの高温度で焼成するもので, 磁器 製造工業が他工業に比べて著しい特異性を持つのはこ の本焼焼成の工程のためである。

a) 酸化焰と還元焰を所定の温度で使いわけなけれ， ばならない。

b) 還元焰では $\mathrm{CO}$ 濃度を絶えず一定に維持しな ければならない。COの存在がないと素地が黄褐 色に変化して製品にならない。

c ）素地の軟化温度と焼成温度の差が小さい。すな わち燒成最終温度の幅が狭く, したがつて歪みを 生じ易い。

以上のよらな磁器本焼焼成の特異性が作業者に高度 の熟練を要求することになり, 製品の安定度は著しく 極限される。計測機器による焼成管理とこれを基礎と しての自動制御化が，他工業に比べて充分に行なわれ ないというよりもほとんど実現されないのも，もつぱ ら熟練に依存する本焼焼成の特異性のためである。

3. 本焼焼成設備

一例として弊社で稼働しているトンネル窯について 概要を述べる。築攽当初は燃料入手の関係上発生炉ガ スを燃料として使用してきたが，戦後は機構の改善を 行ない, 油焚に転換した。窐の概要は第 8 図のごとく である。 


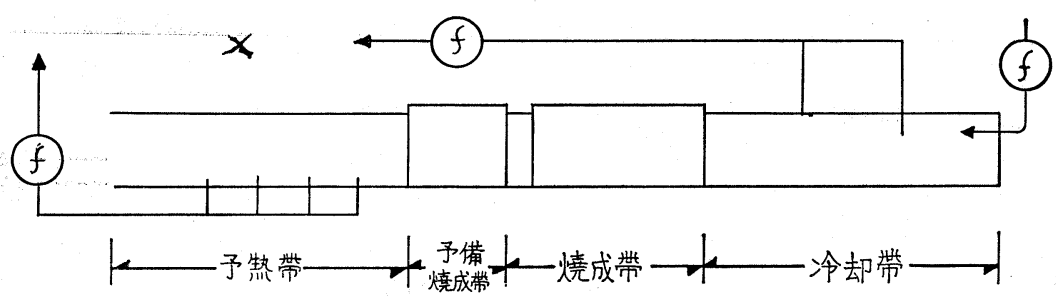

\begin{tabular}{|c|c|c|c|c|c|c|}
\hline \multirow{2}{*}{ 型 } & \multirow{2}{*}{ 被焼成品 } & \multicolumn{2}{|c|}{ 大きさ } & \multirow{2}{*}{ 窯内車台数 } & \multicolumn{2}{|c|}{ バーナ数 } \\
\hline & & 長 & 高 & & 予備焼成帯 & 焼成带 \\
\hline 日陶式 & 磁器洋食器 & $76.9 \mathrm{~m} \quad 1.2 \mathrm{~m}$ & $2.5 \mathrm{~m}$ & 42 & 12 & 24 \\
\hline 焼成温度 & 案内雾囲気 & 加熱方式 & 冷却方式 & 通風法式 & 焼成車台数 & 䉆詰方式 \\
\hline SK 13 & 還元焰 & 直火式 & 兴フルおよび & 強制通風 & 27車/日 & サヤ詰 \\
\hline
\end{tabular}

第 8 図 本焼焼成用トンネル搳の一例

1) 通風

予熱帯下部両側にある数カ所の引穴よりエキゾース

ト・ファンによつて強制通風を行なつている。

2) バーナー

重油燒成におけるバーナ一の重要性はいらまでもな いが，特に還元焰を主とする場合は，少量の噴霧空気 で完全に噴霧化するバーナーが是非共必要となる。こ の場合は予備焼成帯, 焼成帯ともに油と空気とが比例 式に調整できるバーナーを使用してその目的を達して いる。

3) 一次空気 (噴霧空気)

ブロアーにより供給され，バーナー部で 水柱 600 $\mathrm{mm}$ に保つている。な捈中配管を余熱で $40 \sim 50^{\circ} \mathrm{C}$ に加温している。

4) 二次空気

蓄熱帯で熱交換され $150 \sim 160^{\circ} \mathrm{C}$ に加温された外気 をフアフにより強制的にバーナ一先端部に送入し，こ の量によつて各バーナーの還元濃度を調節している。

5）冷却空気

冷却帯に外気をフアンより送入して羹内のサヤおよ び製品と直接熱交換を行なつている。

6) 余 熱

冷却帯でマツフル式の熱交換煉瓦をつうじて窯内の サヤおよび製品と閒接に熱交換を行なつている。また マッフル式でなく直接に葖内の熱気を吸引し, サヤお よび製品を直接冷却することも行なつている。

\section{VI. 計 測 管 理}

1. 計測管理の考え方

陶磁器の焼成は, 高温度還元焼成という特異性によ つて, 計測管理と自動制御化は他工業に較べて非常に 遅れている。焼成管理を実施するにはまず日常の焼成
状況を計測器によつて把握しなければならない。計測 管理に当つては，つぎの点を重点において管理すべき である。

a）品物の組成および形状に適合した温度曲線の設 定

b ）㸃内温度分布の均一化

c ) 案内基準雾囲気の維持

d）案内基準圧力の維持

なかでも焼成帯の䨌囲気の一定化は最も重要な点 で, 燃焼ガス量を一定に保ち, かつ, 予熱帯への流れ を常に一定にし, また冷却帯と焼成帯の境をニュート ラルに保ち，ガスの移動が起らないように維持する。

この基本条件を満足せしめるためには，つぎの処置 が必要である。(第 9 図)

1）焼成車の少ヤ積様式

サヤ積様式を一定に維持することは, 生産内容によ つて，実際的には容易なことではないが，燃焼ガスの 流れを安定させるために是非実施したい点である。サ ヤの形状とならべ方を各燒成車台ごとに同一にして, サヤ相互の空間容積を均一にすることが大切である。 製品とサヤの重量は，著しい変化のない限り二次的に 考えてよい。

2）燒成帯の致内圧の制御

供給する燃料および空気量を一定にし，かつ，排気， ガス量を制御し，焼成帯前部の窯内圧を一定にする。

また, 冷却帯に熱交換用として送入する冷却空気量 と，空内から熱交換によつて回収する熱風量を一定に 保つようにする。

このようにして, 焼成帯の窯内圧を一定にすること が, 焼成工程を安定化させる上に重要な点であり, こ れを計測機器で管理することが必要である。 


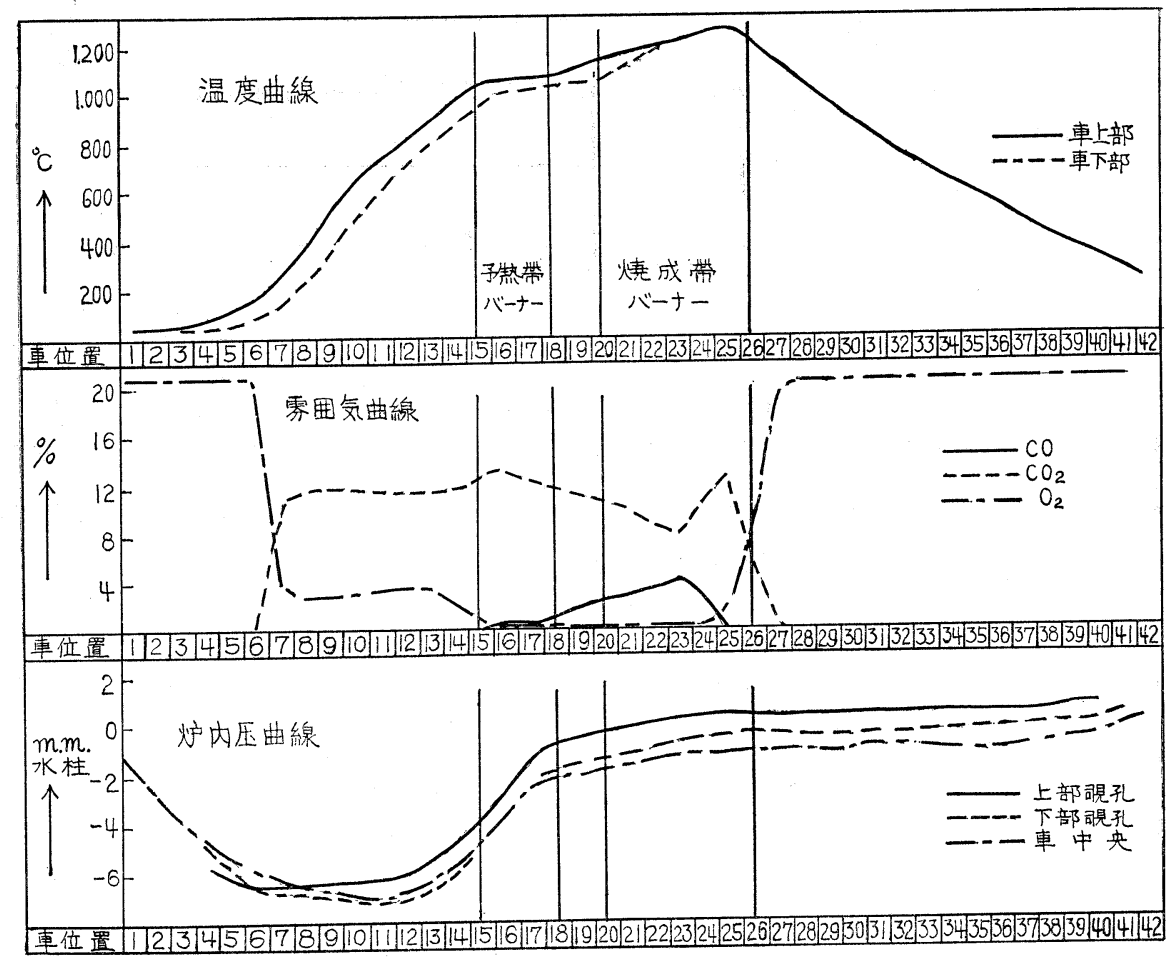

第 9 図 温度, 雾囲気, 炉内圧曲線

3）燒成帯の温度, 雲囲気の調整

燃料の性状, 燃料供給量, 空気供給量を各バーナー ごとに一定規準に設定管理し, 窯内各部の温度および 雲囲気の組成を一定に維持することが大切である。こ の場合に注意すべきは, 燃料および空気の温度管理で ある。

2. 計測管理の実際

温度, 雲囲気を一定に保つために四季の外気温の変 動, 日常の外的条件の変化などに対して然料や空気量 の調節が必要になるが, これはすべて計測器により測 定処理すべきであり, したがつて, 計測器には一定の 規準值を設定する必要がある。この規準值を設定する 方法として, 測定車を害内に所定のごとく進行せしめ る。測定車には温度計器およびガス吸引装置を設置 し, 実際, 焼成される状態で焼成車台を進行しつつ 上，中，下，などの温度およびガス分析を自動記録式 計測器で連続的に測定し, 最も適した設定值を決定す る。この值を基準にして, 窯に装置した計測器の基準 值を定める。

作業者は，すべてこの基準值の範囲内にあるように 制御する。しかし外気温, その他の変動に対しての補

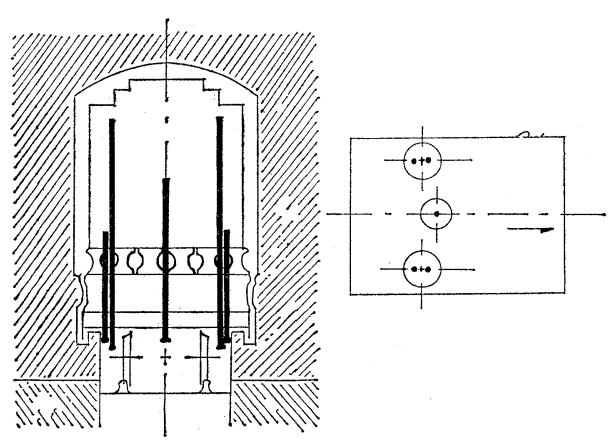

第10図 測 定 車

正は，実際の場合 $5^{\circ} \mathrm{C}$ ごとに補正表にしたがつて実 施すればよい。このような管理を実施することによつ て, 四季の変動も, 焼成結果に変動をきたさないよう になる。

第11図は, 計測器の配置状況を示す。

自動制御としては致内圧制御, 雾囲気制御, 温度制 御の 3 つが考えられる。窝内圧の制御は焼成帯の前後 で行ならことが妥当であり, 焼成帯前部と排気フアン のダンパーを自動制御すればよく，また焼成帯後部の 


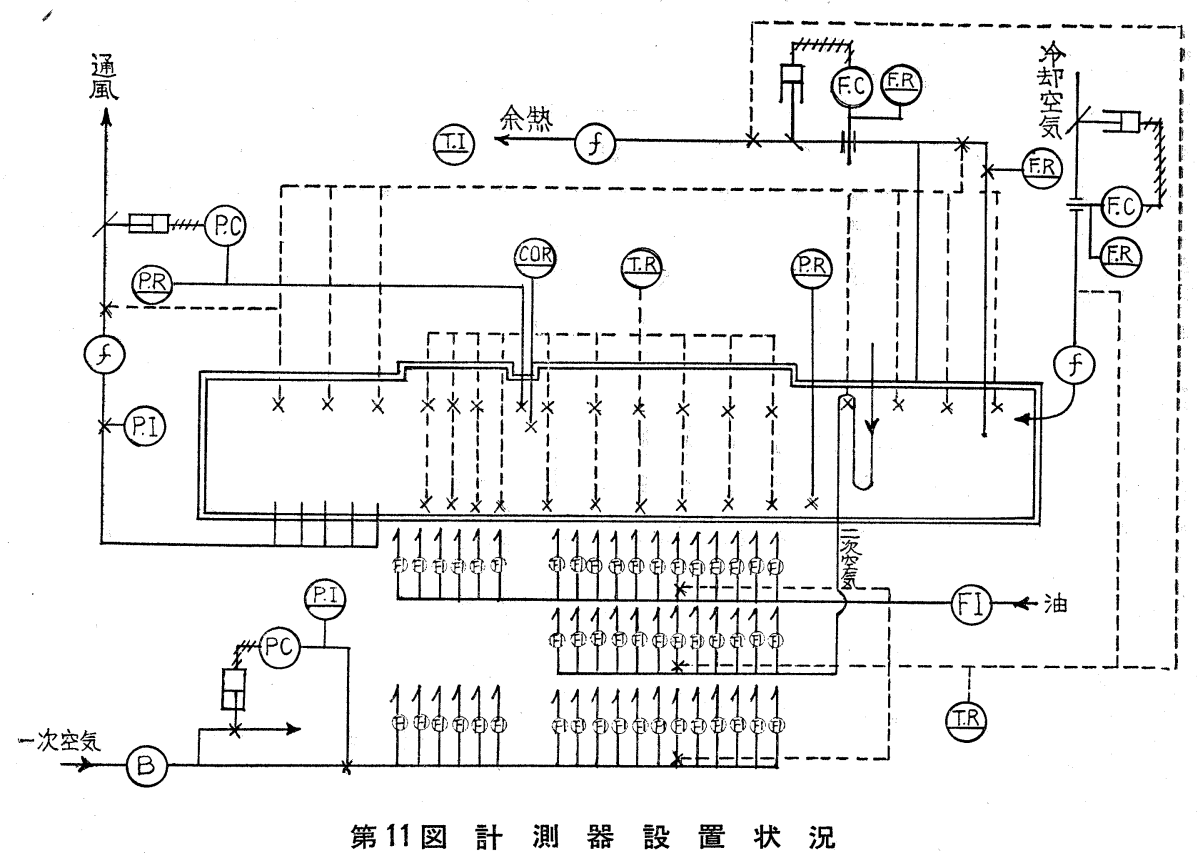

穼内圧は, 冷却帯における熱交換用空気の出入量を制 御する。すなおち, 送入空気量と回収熱吸引量を一定 にすることにより，目的を果すことができる。

雲囲気制御を行ならには, 供給油量と燃焼空気量を 一定にすればよい。このためにはバーナーの性能およ び噴霧用空気と二次空気の運用の研究が必要である。 CO 百分率は計測器により連続測定する。

温度制御は, 燃料および空気量, 空内圧力の制御と 被熱物の送入量の均一化によつて, 自動的に制御でき る。以上のように, 磁器焼成は計測管理によつて半自 動化できるが，焼成諸基準を究明すれば，全自動化の 実現性は夢ではなく，この睦には長足の進歩をする。

\section{VII. 熱エネルギー合理化実施例}

1. 熱勘 定

熱勘定の一例を示すと第12図のごとくである。

1）有効 熱

陶磁器本焼焼成においては, 品物を一個づつサヤに 入れて焼成する。したがつて, 製品は焼成する重量の 約 1/10 位しかない。また高温度還元焰であり，この 種の焼成における有効熱は非常に低いが，第 2 .表のご とく昭和 24 年発生炉ガス焚のトンネル割において焼成 品の熱効率 $1.3 \%$ に過ぎなかつたのが，昭和 35 年油焚 で $\mathrm{SiC}$ 質のサヤを用い $8.1 \%$ と向上，本年 $9.4 \%$ と なつている。

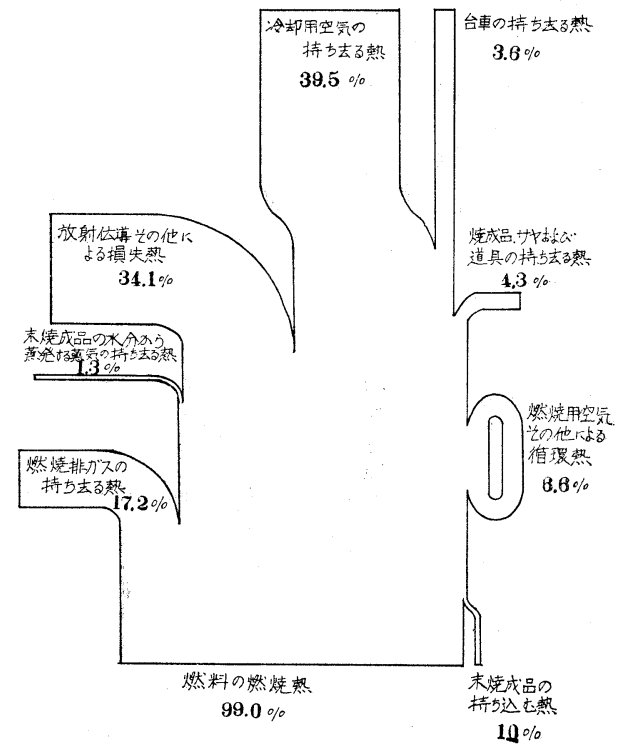

第12図 熱 流 れ 図

$\mathrm{SiC}$ 質のサヤを用いることによつて従来のシヤモッ 卜質のサヤの場合に比べて焼成温度は約 $15^{\circ} \mathrm{C}$ 低下さ せることができただけでなく，重量が約 $30 \%$ 減少し， 製品とサヤの重量比が 1:5 となり焼成品の重量を約 $20 \%$ 増加できた。 
第 2 表 有効 熱および回収熱

\begin{tabular}{|c|c|c|c|c|c|c|}
\hline 晏の種 類 & 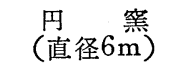 & & r & v & ル & 案 \\
\hline 代 & $\longrightarrow$ 昭 7 & & $8 \longrightarrow 27$ & & $28 \longrightarrow 34$ & $35 \longrightarrow 39$ \\
\hline 料 & 石 & 発 & 生 炉 ガ & ス & 重 & 油 \\
\hline $\begin{array}{l}\text { サヤ 種 類 } \\
\text { 成品の熱効率\% }\end{array}$ & $\begin{array}{c}\text { シャモット質 } \\
0.95\end{array}$ & & $\begin{array}{l}\text { † モット } \\
1.3 \rightarrow 2.6\end{array}$ & 質 & $\begin{array}{c}\text { シャモット質 } \rightarrow \mathrm{SiC} \text { 質 } \\
4.7 \rightarrow 7.4\end{array}$ & $\begin{array}{l}\text { S i C 質 } \\
8.1 \rightarrow 9.4\end{array}$ \\
\hline $\begin{array}{l}\text { サヤおよひび道具\% } \\
\text { を含んだ熱率 }\end{array}$ & 9.90 & & $13.8 \rightarrow 18.2$ & & $43.2 \rightarrow 36.7$ & $38.7 \rightarrow 38.1$ \\
\hline 熱 回 収 率\% & - & & $18.4 \rightarrow 31.9$ & & $34.2 \rightarrow 35.7$ & $38.2 \rightarrow 41.9$ \\
\hline
\end{tabular}

2) 回収熱

トンネル㕓より回収した熱量も回収方法の改善, 焼 成の計測管理により増加し，第 2 表のごとく昭和 24 年 18. $4 \%$ であつたものが，本年 $41.9 \%$ と向上してい る。

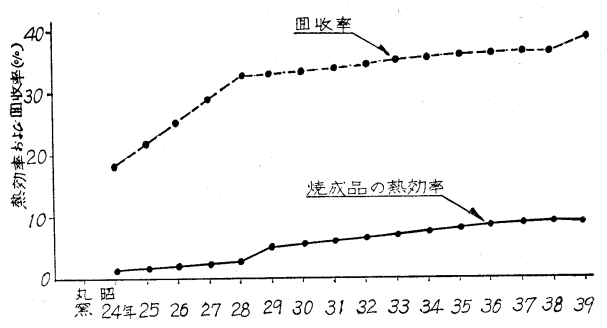

第13図 熱効率と回収率

\section{3) 燃料使用量}

燃料使用量は, $\mathrm{SiC}$ 質サヤの使用, 計測機器使用に よる自動制御の確立実施などにより，過去10年間に約 $25 \%$ の節減を示すに至つた。

製品 $1 \mathrm{t}$ 当りの 昭和 31 年(A) 昭和 30 年(B) $\mathrm{A} / \mathrm{B}$ 使用熱量 $\mathrm{kcal}$

$$
7,700 \times 10^{3} \quad 5,800 \times 10^{3} \quad 75 \%
$$

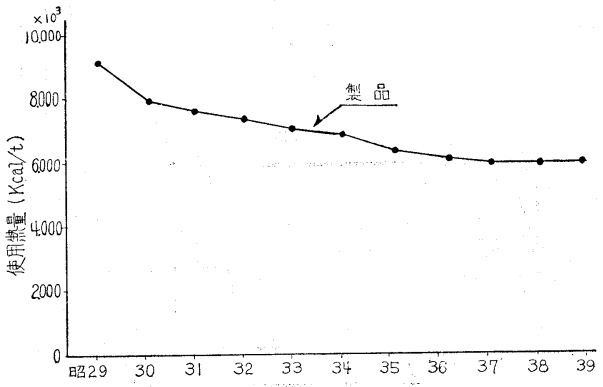

第14図 製品 $1 \mathbf{t}$ 当りの使用熱量

\section{VIII. 結論}

陶磁器工業における熱エネルギー源としての然料の 種類の選択および質的ならびに合理的使用量の変化に ついての変遷を略述した。

上述の説明のごとく燃料の種類の選択および質的要 素の検討は重要であることは論をまたないが，さらに 使用法に対する計測管理および自動制御方式による焼 成管理など研究すべき問題は多々ある。

燃料費が原価中に大きな比重を有する陶磁器工業に おいては, 歩留の向上などと相まつて, 広義における 熱経済を目標に原価低減を実現すれば輸出への途はま すます開けると考える。

\title{
Ceramic Industry and Fuel
}

\author{
by Nobuo Ōishi \\ (Japan Ceramics Co., Ltd.)
}

SYNOPSIS :-The ceramic industry has recently been making remarkable progress coupled with the expansion of the overseas market. According to the diffusion of the heat control techniques and also the improvement of the kilns, fuel consumption has been rationalized and increased by about $30 \%$ for the latest five years together with the increase of the ceramic ware production. As for the fuel as heat energy source in the ceramic industry, the author outlined its selection, rational utilization as well as the changing pattern of its consumption. 